\title{
STATE INJUNCTION OF PROCEEDINGS IN FEDERAL COURTS
}

Ir is a long-standing principle that a court can enjoin the institution or prosecution of a civil action in another court of its jurisdiction to prevent injury to the party requesting the injunction. ${ }^{1}$ But before granting this relief the court must determine whether the injury to the requesting party is sufficient to overcome a reluctance to interfere with the process of other courts. When the injunction is to run against a court in another jurisdiction this reluctance is re-enforced by a natural desire of the issuing court not to interfere with another sovereign. ${ }^{3}$ In a federal system this problem can arise in three contexts: state court injunctions against proceedings in the courts of other states (interstate injunctions); state court injunctions against proceedings in federal courts (state-federal injunctions); and federal court injunctions against proceedings in state courts (federal-state injunctions).

The law governing these three kinds of inter-court injunctions is not the same. Federal-state injunctions have always been controlled by federal statute. ${ }^{3}$ Under 28 U.S.C. $\$ 2283$ a federal court can enjoin state proceedings "where necessary in aid of its [the federal court's] jurisdiction, or to protect or effectuate its judgments." Interstate injunctions are restricted by neither federal statute nor federal decisional law and are allowed in all circumstances which would justify the grant-

1. The courts most frequently speak of irreparable or irremediable injury. E.g., State Corp. Comm'n v. W'ichita Gas Co., 290 U.S. 561, 568 (1934); Brown v. Purvin, 52 F. Supp. 348, 349 (S.D.N.Y. 1943).

2. See Burford v. Sun Oil Co., 319 U.S. 315 (1943) (federal equity courts should respect state governments' interest in furthering their domestic policy); Blanchard v. Commonwealth Oil Co., 294 F.2d 834, 839 (5th Cir. 1961); Note, State Injunctions Against Pro. ceedings in the Federal Courts, 90 U. PA. L. Rev. 714, 715 \& n.10, 728-29 (1942).

3. The Act of March 2, 1793, ch. 22, §5, 1 Stat. 335 forbade the use of injunctions by the federal courts "to stay proceedings in any court of a state." This was re-cnacted, without significant change, as REv. STAT. § 720 (1875), and later as Act of March 8, 1011, ch. $231, \S 265,36$ Stat. 1162. Charles Warren viewed the original enactment as a reflection of the apprehension of early Congresses against federal court encroachment on statc jurisdiction. Warren, Federal and State Court Interference, 43 HARv. L. Rev. 345, 347 (1930). But see Toucey v. New York Life Ins. Co., 314 U.S. 118, 129-82 (1911). The Toucey case also recognized that exceptions to the statute had been developed by the courts but limited them to the one recognized for in rem cascs. $1 d$. at 134-41. The present version of the statute, 28 U.S.C. $\$ 2283$ (1958), was an attempt to restore the law as understood prior to Toucey. See H.R. Rep. No. 308, 80th Cong., 1st Sess. Al82 (1947). But see Amalgamated Clothing Workers v. Richman Bros. Co., 348 U.S. 511, 515-16 (1955). 
ing of an intra-system injunction. ${ }^{4}$ State-federal injunctions are not regulated by federal statute, 5 but are regulated by federal decisional law. Apparently the earliest significant pronouncement on state-federal injunctions was made in 1836 by Story in his CoMmrentarIes on EQurrY JURISPRUDENCE that "the State Courts cannot enjoin proceedings in the Courts of the United States."6 This view was generally accepted, and most state courts agreed that they lacked power to enjoin federal proceedings, or at least that comity prevented the exercise of this power. ${ }^{7}$ In spite of this general agreement, until recently the position of the United States Supreme Court was unclear. ${ }^{8}$ The Court had held that state courts could not enjoin the execution of federal judgments. But it had held also that a state-federal injunction could be issued to protect the prior in rem jurisdiction of a state court ${ }^{10}$ and had intimated in dicta that state courts could enjoin federal in personam proceedings. ${ }^{11}$ Recently the Supreme Court clarified its position in Donovan $v$.

4. The United States Supreme Court has reviewed an inter-state injunction in only one case, Cole v. Cunningham, 133 U.S. 107 (1890), holding that the injunction did not violate Article 4, sections $I$ and 2 of the United States Constitution, the Full Faith and Credit or Privileges and Immunities Clauses. Earlier state cases indicated that courts were more reluctant to grant relief inter-state than intra-state, Note, When Courts of Equity Will Enjoin Foreign Suits, 27 Iowa L. Rev. 76, 86 \& nn. 55-58 (1941). But the present tendency is to follow ordinary equitable principles in both situations. See Comment, Injunctions of State Courts Restraining Parties From Proceeding in the Tribunals of Other States, 31 Mrch. L. REv. 88, 89 \& n.4 (1932), Comment, Injunctions Against Suits in Foreign Jurisdictions, $10 \mathrm{LA}$. L. REv. 302, 305 (1950). There is, however, some question as to what recognition will be accorded such an injunction in the second state. Sce James v. Grand Trunk Western R.R., 14 Ill. 2d 356, 152 N.E.2d 858 (1958).

5. While it is not entirely clear that Congress could pass such a statute, Supreme Court opinions have spoken of a congressionally created "right" to be in a fedcral court. Donovan v. City of Dallas, 377 U.S. 408, 412-13 (1964). It would follow that Congress could declare that this jurisdictional right may not be defeated by state court injunctions. See Note, 90 U. PA. L. REv. 714, 729 n.98 (1942).

6. 2 STORY, EQUITY JURISPRUDENCE 186 (Ist ed. 1836).

7. For a compilation of cases see nn.10-25 and accompanying text in Note, $90 \mathrm{U}$. PA. L. REv. 714, 715-18 (1942).

8. The major cases are thoroughly dealt with in Arnold, State Power to Enjoin Federal Court Proceedings, 51 VA. L. REv. 59, 64-70 (1965) [hereinafter cited as Amold].

9. Riggs v. Johnson County, 73 U.S. (6 Wall.) 166 (1867); Central Nat'l Bank v. Stevens, 169 U.S. 432 (1898).

10. Princess Lida v. Thompson, 305 U.S. 456 (1939). This was parallel to the in $\mathrm{rem}$ exception recognized in Toucey, supra note 3.

11. Baltimore \& O.R.R. v. Kepner, 314 U.S. 44 (1911). An Ohio court had enjoined a harassing action brought under the Federal Employers' Liability Act in a federal district court of New York. The Supreme Court disapproved the injunction on the basis of the special venue provisions of the FELA. However, the Court also stated: "petitioner asserts power, abstractly speaking, in the Ohio court to prevent a resident under its jurisdiction from doing inequity. Such power does exist." (Emphasis added.) Id. at 51.52. Justice 
City of Dallas ${ }^{12}$ which held that state courts were completely without power to restrain federal court proceedings. The Court recognized only one exception-"where a [state] court has custody of property, that is, proceedings in rem or quasi in rem."13

Although commentators usually do not attack the result in the Donovan litigation, ${ }^{14}$ they do criticize the Supreme Court's opinion on two grounds: first, that it states too broad a prohibition against statcfederal injunctions and thereby prevents their use when such injunctions might be appropriate; ${ }^{15}$ second, that the in rem exception to the prohibition is also too broadly stated and that it encompasses cases in which state-federal injunctions should not be allowed. ${ }^{10}$ The validity of the first criticism depends on whether the Donovan litigation presents the strongest case for issuing a state-federal injunction. If so, and if the denial of an injunction in Donovan itself is correct, then the scope of the Supreme Court's in personam rule is correct also. The validity of the second criticism will be discussed later, since it depends largely on conclusions about the first.

The Donovan litigation originated as a class action brought by Dallas citizens in a Texas court. They sought to restrain the city's construction of an additional runway at the municipal airport and to prevent Dallas from issuing revenue bonds to finance this construction. ${ }^{17}$ The plaintiffs urged that construction of the runway would result in a taking of their property without due process of law. ${ }^{18}$ The Texas

Frankfurter, dissenting on the construction of the venue provisions, was careful to note that "the decision [did not] give new currency to the discredited notion that there is a general lack of power in the state courts to enjoin proceedings in federal courts." $I d$. at 56.

12. 377 U.S. 408 (1964).

13. Id. at 412 .

14. One commentator specifically approves the Donovan result. Arnold 78.74. Two others are concerned about the broad reach of the decision but attempt littlc analysis of the actual case. Developments In The Law-Injunctions, 78 HARv. L. REv. 994, 1058.54 (1965); Note, State Injunction of Federal Proceedings, 59 Nw. U.L. REv. 832 (1965). And one feels the decision is incorrect, but believes the opposite argument "has merit." Comment, Anti-Suit Injunctions Between State and Federal Courts, 32 U. Cul. L. REv. 471, 502 \& n.164 (1965).

15. Arnold 74-75; Comment, 32 U. CHI. L. REv. 471, 501-02 (1965); Notc, 59 Nw. U.L. REv. 832, 838 (1965).

16. Arnold 73 .

17. Record, pp. 35-36, Donovan v. City of Dallas, 377 U.S. 408 (1964) [hereinafter cited as Record].

18. All claims, including those alleging property damage, existence of a nuisance and violations of Texas statutes are disposed of in Atkinson v. City of Dallas, 853 S.W.2d 275 (Tex. Civ. App. 1961). 
court rendered summary judgment in favor of the city. ${ }^{10}$ The plaintiffs' unsuccessful efforts to appeal finally ended when the United States Supreme Court denied certiorari.20 Following this final disposition of the state proceedings, some of the plaintiffs joined by other Dallas citizens brought suit against the city in the federal district court sitting in Dallas, raising again the due process issue and requesting substantially the same relief which the Texas courts denied them."1 Under Texas law revenue bonds could not be issued while pending litigation challenged their validity. Apparently the plaintiffs wanted to delay the issuance of these bonds as long as possible. 22 The city pleaded res judicata in the federal court, ${ }^{23}$ and also obtained an injunction from a Texas court which forbade both the prosecution of the federal suit and the institution of further litigation in any other court..4 The federal district court dismissed the suit because it did not raise any justiciable issue. ${ }^{25}$ The plaintiffs did not appeal from this dismissal

19. Atkinson v. City of Dallas, No. 59027-H, 44th Judicial D.C. of Dallas County, Texas, July 17, 1961. This unreported opinion is summarized in Atkinson v. City of Dallas, 353 S.W.2d 275, 276 (Tex. Civ. App. 1961).

20. 370 U.S. 939 (1962).

21. Brown v. City of Dallas, Civil No. 9276, N.D. Texas, Mlay 9, 1963. Sce Record 255-63. There were 120 plaintiffs, 27 of whom had been involved in the Athinson litigation.

22. See Tex. Rev. Crv. Stat. art. 1269j-5 \& 3 (1961) and the interpretation given this provision in City of Dallas v. Dixon, 365 S.W.2d 919, 925 (Tex. 1963). Throughout the Iong litigation, all motions and actions by the Dallas citizens were made at the last possible moment. See generally Record.

23. Record 268-69, 272-73. Apparently the City made no attempt to have this issue set for hearing.

24. Id. at 80-81. The injunction $\operatorname{ran}$ against the federal court plaintifs and their attorney, James P. Donovan. This injunction was issued after considerable litigation by the City. In City of Dallas v. Brown, 362 S.Wv.2d 372 (Tex. Civ. App. 1962) the Court of Civil Appeals determined there was no need for injunctive relief since the plea of res judicata in the federal court would adequately protect its jurisdiction and the parties. On petition for mandamus, the Texas Supreme Court directed the lower court to issue the injunction, since in the light of the special provisions for revenue bonds any further litigation would destroy the efficacy of the Atkinson judgment. Because the question arose in a mandamus proceeding, the Texas Supreme Court had to find that it was mandatory that the Court of Civil Appeals protect its jurisdiction by means of an injunction. City of Dallas v. Dixon, 365 S.W.2d 919, 925 (Tex. 1963).

25. Brown v. City of Dallas, Civil No. 9276, N.D. Texas, May 2, 1963 . See Record 306. Donovan and the plaintiffs initially paid little heed to the state court injunction. After its issuance, they not only continued the Brown suit in the federal district court until it was dismissed, but also instituted in that court a new suit in which an injunction was requested to restrain the individual judges of the Texas Supreme Court and the Court of Civil Appeals from interfering with the suit in the federal court. Donovan v. Supreme Court of Texas, Civil No. CA-3-63-120, N.D. Texas, April 23, 1963, dismissed May 16, 1963; cert. denied, 375 U.S. 878 (1963). See Record 316. 
because the state court threatened prosecution, ${ }^{26}$ but they did obtain a writ of certiorari from the United States Supreme Court to review the Texas injunction..$^{27}$

The Supreme Court reversed in a six to three decision. ${ }^{28}$ The broad prohibition that the Court announced against state-federal injunctions was based upon two grounds. First, the Court maintained that it was only following an "old and well-established judicially declared rule."20 Second, the Court stressed that Congress had given the plaintiffs a "right" to bring suit in a federal court and that this right required the federal court to decide the issues presented by the plaintiffs. ${ }^{30}$ The dissenters, concurring in the opinion of $\mathrm{Mr}$. Justice Harlan, found that the "old and well-established" rule permitted the injunction to prevent harassing litigation. ${ }^{31}$ They also attacked the majority's reliance upon the "right" created by Congress, arguing that the existence of this right was the very question at issue and that the reliance was inconsistent with the in rem exception recognized by the Court. ${ }^{32}$ The majority might have been criticized further since it relied so heavily on plaintiffs' indefeasible right and therefore did not consider some of the conflicting interests relevant to the case.

The majority in Donovan could have reached the same result by considering all the relevant interests. There are two interests supporting a state-federal injunction-the interest of the parties in being free from duplicative litigation and the interest of the enjoining sovereign in protecting the process of its courts. And there are three interests

26. A notice of appeal was filed with the federal district court. Record 311. This was later withdrawn, $i d$. at 314 , but counsel Donovan made it clear he was acting under duress. In the meantime, Donovan and many of his clients were found guilty of contempt by the Texas Court of Civil Appeals. City of Dallas v. Brown, 368 S.W.2d 240 (Tex. Civ. App. 1963). Donovan himself spent 20 days in the Dallas county jail.

27. Donovan v. City of Dallas, 375 U.S. 878 (1963). Donovan had requested a writ of certiorari to review four judgments: the decision of the Texas Supreme Court in favor of the state-federal injunction, the contempt convictions by the Texas Court of Civil Appeals and the dismissals of the two suits brought in the federal district court. The writ was not granted as to the latter two.

28. Donovan v. City of Dallas, 377 U.S. 408 (1964). Mr. Justice Black vacated the contempt convictions because the injunction on which they had been based was invalid. On remand, the motion to hold in contempt was denied. City of Dallas v. Brown, 884 S.W.2d 724 (Tex. Civ. App. 1964).

29. Donovan v. City of Dallas, 377 U.S. $408,412.13$ (1964).

30. Ibid.

31. Id. at 414-18. The dissenters felt the question presented was not the gencral one of state court power to enjoin all in personam proceedings in the federal courts, but the narrower one of state court power to enjoin vexatious, duplicative litigation which would thwart a previously rendered state-court judgment. Id. at 414-15.

32. Id. at 420-21. 
operating against the injunction-the interest of the enjoined sovereign in protecting the process of its courts, the common interest in avoiding inter-court interference, and the common interest in preventing interference between sovereigns. ${ }^{33}$ The decision of the Texas Supreme Court indicates that the parties' interest in avoiding future litigations was greater than the interest against inter-court interferences since the injunction would have been valid if it had been directed against another Texas court..34 The Supreme Court could have reversed the Texas Supreme Court on either of two assumptions. The Court could have found that the federal interest in protecting federal courts exceeded the state interest in protecting state courts. ${ }^{35}$ Or the Court could have found that these two interests were equal but that the common interest in preventing interference between the states and the federal government, when combined with the interest against inter-court interference, exceeded the parties' interest. ${ }^{36}$ However, only the former possibility accounts for the federal courts' power to enjoin state proceedings. If a case identical in all respects to Donovan had been brought in federal court, the same five interests would be relevant. The parties' interest in obtaining the injunction, and the common interests in preventing inter-court and inter-sovereign friction would be the same. However, unlike the Donovan case, here the federal interest would support the injunction and the state interest would oppose it. ${ }^{37}$ In this case a federal-state injunction would have been clearly permissible under 28 U.S.C. $§ 2283 .{ }^{38}$ The imagined transposition demonstrates that

33. There is no opinion in which all five of these interests have been recognized, but some of the five have been noted in separate opinions. See notes 1-2 supra and accompanying text.

While it is obvious that no exact mathematical analysis of injunctions is possible, it is helpful to use inequalities to clarify the relationships being discussed. If $p=$ partics" interest, $s=$ state interest, $f=$ federal interest, $c_{1}=$ common interest in preventing intercourt interference and $c_{2}=$ common interest in preventing inter-system interference, then $\mathrm{p}+\mathrm{s}$ favors the state-federal injunction and $\mathrm{f}+\mathrm{c}_{1}+\mathrm{c}_{2}$ operates against it.

34. In equality notation, $p>c_{1}$. This is a certainty since the injunction banned all actions, present or future, in any court. Record $80-81$. See also note 24 supra.

35. That is, $f>s$. The Texas Supreme Court decision, when put in this interest analysis context, means that $\mathrm{p}+\mathrm{s}>\mathrm{f}+\mathrm{c}_{1}+\mathrm{c}_{2}$. If $\mathrm{f}>\mathrm{s}$, this can be reversed so that $p+s<f+c_{1}+c_{2}$

36. If $\mathrm{f}=\mathrm{s}$, then the Texas court determined that $\mathrm{p}>\mathrm{c}_{1}+\mathrm{c}_{2}$. The $\mathrm{p}>\mathrm{c}_{1}$ determination of the Texas court would not be reviewable since it raises no federal question, but the Supreme Court could reverse by finding $p<c_{1}+c_{2}$ and that therefore $p+s<f$ $+c_{1}+c_{2}$. This would mean $c_{2}$ was the crucial factor in the reversal.

37. Thus, the total factor favoring the injunction would be $p+f$ and $s+c_{1}+c_{2}$ would be against.

38. 28 U.S.C. \$ 2283 (1958) specifically permits a federal-state injunction "to protect or effectuate [federal court] judgments." See, e.g., Jacksonville Blow Pipe Co. v. Recon- 
Donovan could have been decided properly only upon the assumption that the federal interest exceeds the state interest. ${ }^{30}$

Assuming that the preceding catalogue of interests is complete, it is possible to test whether or not the broad Donovan rule follows from the decision in that particular litigation by determining whether there are any situations which would present a stronger case for issuing a state-federal injunction than Donovan itself.40

The state's interest in Donovan was in protecting its court's judgment. It is possible that a state may have a greater interest in protecting its courts' jurisdictions or ensuring access to its courts. ${ }^{41}$ But no court, state or federal, has ever been more zealous in protecting its jurisdiction or access than in protecting its judgments. ${ }^{42}$ For example, the Supreme Court has always refused to permit any state court interference with a federal judgment ${ }^{43}$ although the power of a state court to interfere with access to federal courts was unclear until Donovan. ${ }^{44}$ Furthermore, 28 U.S.C. $\S 2283$ permits a federal court to use injunctions to protect both its jurisdiction and its judgments, but the jurisdiction provision has been construed more narrowly than the judgment provision. ${ }^{45}$

struction Fin. Corp., 244 F.2d 394 (5th Cir. 1957); Jackson v. Carter Oil Co., 179 F.2d 524 (10th Cir. 1950). Thus, $\mathrm{p}+\mathrm{f}>\mathrm{s}+\mathrm{c}_{1}+\mathrm{c}_{2}$ in this situation.

39. That is, Donovan itself gives us $p+s<f+c_{1}+c_{2}$. The hypothetical situation would result in $p+f>s+c_{1}+c_{2}$. Since the hypothetical is constructed so that $p, c_{1}$ and $c_{2}$ are the same as in Donovan, the two cases are consistent only if $f>s$. If $f=s$, the injunction in the hypothetical would be impossible since transposing $f$ with $s$ would not change the direction of the inequality.

40. I.e., if $\mathrm{p}+\mathrm{s}$ is a maximum in Donovan, and $\mathrm{f}+\mathrm{c}_{1}+\mathrm{c}_{2}$ a minimum, then acceptance of the Donovan result itself compels the conclusion that the rule announcel in the case is not stated too broadly. A writer of a recent article has argued that the Donovan result was correct since there were adequate federal remedies available. Arnold 73.74. This Note accepts that argument but questions the writer's conclusion that the rule announced in the case was too broadly stated.

41. Courts tend to speak of the occurrence of interference with their jurisdiction regardless of the stage of the proceedings involved. Sec City of Dallas v. Brown, 362 S.W.2d 372, 374-75 (Tex. Civ. App. 1962). But distinctions of this nature have been made. Sce Note, 90 U. PA. L. Rev. 714 (1942); Fort v. Lang Co., 118 N.J. Eq. 527, 180 Atl. 395 (Ch. 1935); Wheeler v. Vimalert Co., 235 App. Div. 643, 255 N.Y. Supp. 114 (1932).

42. Res judicata has been thoroughly developed to assure protection of prior judgments. See 1B MoOre, Federal Practice (2d ed. 1965) which is devoted entircly to res judicata and related doctrines. There is no equivalent method for protecting jurisdiction or access.

43. Riggs v. Johnson County, 73 U.S. (6 Wall.) 166 (1867); McKim v. Voorhics, 11 U.S. (7 Cranch) 279 (1812). For a state court decision sharing this view, sce Fort v. Lang Co., supra note 41 .

44. See Poole v. Mississippi Publishers Corp., 208 Miss. 364, 44 So. $2 \mathrm{~d} 467$ (1950) cnjoining a threatened federal suit. But see Royster Guano Co. v. Stedham, 178 Ga. 217, 172 S.E. 555 (1934).

45. See la Moore, Federal Practice $100.224,0.225$ (2d cd. 1965). 
The second interest supporting a state-federal injunction-the interest of the parties in avoiding duplicative litigation-is the most difficult to evaluate. The strength of this interest depends on both the potential harm to the party seeking the injunction and the adequacy of the federal procedures which can be used to remedy this harm." In Donovan the city was disadvantaged by the trouble and expense of defending a second suit, and by the uncertainty of having its prior judgment upset. The fact that the revenue bonds could not be issued while the federal litigation was pending aggravated this disadvantage. The remedy most readily available to the City of Dallas was a plea of res judicata in the federal court. ${ }^{47}$ Generally the plea is raised by a motion under Rule 12 (b)(6) for dismissal for "failure to state a claim upon which relief can be granted." This motion can be disposed of in a pre-trial hearing. 4 If it is necessary to consider depositions or affidavits then the court may treat the Rule 12(b)(6) motion as a motion for summary judgment under Rule 56. ${ }^{49}$ Ordinarily, however, the res judicata defense will present only a question of law for the court and will not require an evidentiary hearing. ${ }^{50}$ In either case, relief is quick and inexpensive. In Donovan, however, the disposition of the res judicata issue could be appealed, thereby further preventing the issuance of the revenue bonds. ${ }^{51}$

46. The first element usually involves a determination by the trial court of the relative inconvenience or injury to the parties. 43 C.J.S. Injunctions $\$ 30$ (1945). The federal courts refer to this as the "balance of convenience test." Harris Stanley Coal \& Land Co. v. Chesapeake \& O. Ry., 154 F.2d 450, 454 (6th Cir. 1946). The second element is the familiar rule that there can be no injunction where there is an adequate legal remedy. See id. at 453. But see Developments In The Law-Injunclions, 78 HARv. L. REv. 994, 1019-21 (1965).

47. See note 23 supra and accompanying text.

48. FED. R. Crv. P. 12(d) specifically provides for preliminary hearings for a 12(b)(G) defense whether raised by motion or in a pleading. The hearing is held at the discretion of the court, but the thrust of the Rule is to expedite relief. See 2 MIOORE, FEDERAL Practice If 12.16 (2d ed. 1964).

49. FED. R. Crv. P. 12(b). The 5th Circuit has specially applied this to the defense of res judicata. Larter \& Sons v. Dinkler Hotels Co., 199 F.2d 854, 855 (5th Cir. 1952). See 6 MoonE, FEDERAI PRACTICE If 56.02[3] (2d ed. 1953).

50. See id. at II 56.17[52].

51. There was in fact an attempted appeal of the dismissal of the federal action in Donovan. See note 31 supra. But it was also obvious that Donovan, wishing to keep this case in court as long as possible, would appeal the injunction granted by the state court. An appeal of a federal court determination of a question of res judicata would almost certainly not reach the Supreme Court, while an appeal of the state-federal injunction, which sets the problems of federalism forth in high relief, was almost certain to pass through the state court system and then to the United States Supreme Court. It is difficult to understand why the city would prefer the injunction unless an appeal of such action would not interfere with the issuance of the revenue bonds. There has been no judicial construction of the statute governing bond issues, TEx. REv. Crv. Stat. art. 1269j.5 § 3 
It does not seem likely that any other situation would present as compelling a case for the issuance of the state-federal injunction as Donowan. For example, most cases would be very similar to Donovan ${ }^{\text {b2 }}$ (relitigation in a federal court of an action brought to judgment in a state court), except that complications analogous to those created by the Texas law governing bond issues probably would not be present. But even if similar complications did appear, the federal remedies available would be the same as in Donovan.

There is no greater need for an injunction when plaintiff brings concurrent suits in both state and federal courts. The initial suit might be brought in either. In both situations the harm to the defendants is the same-the trouble and expense of defending two separate actions based upon the same claim. And in either case the disadvantage to the defendant is less than in Donovan because no expectations arising out of a final judgment have been upset. The remedies available in these two situations, however, are not necessarily the same.

When the plaintiff brings his first action in a state court, the most appropriate remedy for the defendant would be a stay of the federal suit. Stays in federal courts have long been granted in deference to earlier federal proceedings. ${ }^{53}$ Some early Supreme Court cases indicated, however, that stays could not be granted merely because there was a pending state proceeding of the same action. ${ }^{54}$ But this view has been

(1963). However, that section recpuires the approval of the Attorney General of Texas for any bond issues. It seems unlikely such approval would be given while the injunction issue was being appealed.

This discussion of the parties' interest has been directed at those situations in which the defense of res judicata is clearly applicable-the parties and the issues being Identical. Should it not be clear that this defense is available, the federal remedy open to the party is less certain, but correspondingly the potential harm threatened by the second suit is also less, since if res judicata is not allowed it is because the second suit is not a rclitigation of the first.

52. Since the state and federal courts involved in Donovan were both located in Dallas, the trouble and expense to the parties did not include the added element of a distant federal forum. For this additional harm there appear to be adequate federal remedles. $A$ party bringing suit in a distant forum must overcome problems of jurisdiction and venuc and even when these hurdles are overcome there is 28 U.S.C. $\S 1404$ (a) (1958) which pro. vides for a transfer to a more convenient forum.

53. See e.g., Schwartz v. Kaufman, 46 F. Supp. 318 (E.D.N.Y. 1940); Ryan v. Scaboard \& R. R.R., 89 Fed. 397 (C.C.E.D. Va. 1898). The power to stay procecdings is incidental to the inherent power in the federal courts to control their dockets, Landis v. North Am. Co., 299 U.S. 248, 254 (1936).

54. See McClellan v. Carland, 217 U.S. 268 (1910); Chicot County v. Sherwood, 148 U.S. 529, 534 (1893). See also Kline v. Burke Constr. Co., 260 U.S. 226, 234-35 (1922). While the Court in McClellan explicitly reversed a lower court order staying federal procecdings so that an action might be instituted in a state court, it carefully refused to pass upon the validity of a stay if state proceedings are already under way when the federal suit is commenced. McClellan v. Carland, supra at 282-83. 
changing and several courts of appeals have affirmed the power of district courts to stay federal suits when prior state actions ${ }^{65}$ were pending. The position of the Supreme Court, however, remains unclear. But the Court's acceptance of abstention and forum non conveniens indicates that it does not feel that federal jurisdiction must be furthered at all costs. $^{56}$ Moreover, the Supreme Court has recognized the discretionary power to issue stays in limited areas controlled by special jurisdictional statutes. ${ }^{57}$ And Donovan itself, which prevents a state court from enjoining the federal proceeding makes it necessary for the federal courts to grant stays in order to protect the defendant. ${ }^{.8} \mathrm{~A}$ stay, though, is not a final disposition, and therefore it might not protect defendants completely. But when the state court renders a decision, defendant could move for a summary dismissal under Rule 12 or Rule 56.50 Therefore, if the Supreme Court continues to allow the lower courts to employ stays, the harassed defendant has an adequate federal remedy.

When the state action is brought after the federal suit, the federal court will probably not grant a stay, especially if the federal suit has gone to trial. ${ }^{60}$ However, defendant may protect himself by requesting a stay in the state proceeding. If state law permits such stays, the defendant has an effective remedy. ${ }^{61}$ If state law does not permit such relief, defendant may seek a federal-state injunction. Although Kline v. Burke Constr. Co ${ }^{62}$ held a federal-state injunction could not be issued under such circumstances, that case has been undermined by Donovan. ${ }^{.3}$

55. See, e.g., Mottolese v. Kaufman, 176 F.2d 301 (2d Cir. 1949); Butler v. Judge, 116 F2d 1013 (9th Cir. 1941). Since a stay sets the stage for a later dismissal on a plea of res judicata, or at least permits some issues to be decided by a state rather than a federal tribunal, at least one circuit has found such discretionary stays to be bejond the power of a federal court. Ermentrout v. Commonwealth Oil Co., 220 F.2d 527 (5th Cir. 1955); Maryland Cas. Co. v. Glassell-Taylor \& Robinson, 156 F.2d 519 (5th Cir. 1946).

56. See Martin v. Creasy, 360 U.S. 219 (1959); Alabama Pub. Serv. Comm'n v. Southern Ry., 341 U.S. 341 (1951); Gulf Oil Corp. v. Gilbert, 330 U.S. 501 (1947). For a more complete discussion and citation of authority, see Note, Stays of Federal Proceedings in Deference to Concurrently Pending State Court Suits, 60 Colux. L. REv. 684, 688-92 \& nn.29-37 (1960); Note, Power to Stay Federal Proceedings Pending Termination of Concurrent State Litigation, 59 YALE L.J. 978, 980-81 \& nn.6-12 (1950).

57. Langues v. Green, 282 U.S. 531 (1931) (admiralty jurisdiction); Brillhart v. Excess Ins. Co. of America, 316 U.S. 491 (1942) (declaratory judgment).

58. The stay can be granted even when a state court would not enjoin the federal court. Note, 60 ColuM. L. REv. 684, 698-709 (1960).

59. FED. R. Crv. P. 12, 56. The dismissal should be rapid since the decision to stay the federal action requires a determination that the state court action involves similar issues and parties.

60. In re President \& Fellows of Harvard College, I49 F.2d 69 (Ist Cir. 1945): Pan. Am. Airways, Inc. v. Consolidated Vultee Aircraft Corp., 87 F. Supp. 926 (S.D.N.Y. 1949).

61. See Note, 59 Yale L.J. 978, 979 \& nn.1-3 (1950).

62. 260 U.S. 226 (1922).

63. The Court apparently did not realize the full implications of its holding since Kline 
Kline denied the federal-state injunction largely on the ground that federal jurisdiction was merely statutory. ${ }^{64}$ Donovan, on the other hand, repeatedly stressed the importance of the right given individuals by Congress to have their causes heard and determined in federal court. ${ }^{65}$ The rationale of Kline was that "the rank and authority of the courts [state and federal] are equal." ${ }^{60}$ Donovan's implicit rationale was that there is a greater federal interest in protecting the process of federal courts. ${ }^{67}$ Moreover, Donovan's reliance upon federal relief to protect defendants also requires that a federal court issue an injunction against a state court when there is prior federal jurisdiction and when the state court refuses to stay its proceedings..$^{08}$

is used as authority for the proposition that concurrent suits will not be enjoincd. 377 U.S. at 412 .

64. The Court of Appeals determined that a "constitutional right was granted to the Burke Company to ask and to have a trial and adjudication . . . by the federal court," and that right came from the Constitution and acts of Congress pursuant thereto. 260 U.S. at 233. The Supreme Court answered that "the right of a litigant to maintain an action in a federal court ... is not a right granted by the Constitution ... [but] a right ... which comes into existence only by virtue of an act of Congress. . ." Id. at 238-34. The determination that the Company had only a statutory right meant no relief would be given.

65. The language used was:

But plaintiffs in the second suit chose to file that case in the federal court. They had a right to do this, a right which is theirs by reason of congressional enactments passed pursuant to congressional policy.

Donovan v. City of Dallas, 377 U.S. 408, 412 (1964). See also id. at 418.

66. 260 U.S. at 235.

67. See notes 33-39 supra and accompanying text. The Donovan rationale should have a widespread impact on federalism, for it is obvious that the Court has given new meaning to the congressional legislation vesting power in the federal courts. For the prevlous view. see Justice Frankfurter dissenting in Baltimore \& O.R.R. v. Kepner, 314 U.S. 44, 56 (1941). The development of state-federal relations has advanced another step in the direction indicated by Byrd v. Blue Ridge Rural Elec. Co-op., 356 U.S. 525 (1958). Therc the federal interest in applying a particular mode of trial tipped the scalcs away from the Erie policy of uniformity.

There is also some recognition of a superior federal interest indicated by the application of the removal statute (28 U.S.C. $\$ \S 1441-50(1958)$ ) to federal question cases. These cascs present no problem of an impartial forum as do diversity situations. The only apparent rationale for the removal statute is that federal courts are better able to decide federal questions.

68. Since Donovan indicates $\mathrm{f}>\mathrm{s}$, and the circumstances presented in the text maximize $\mathrm{p}, \mathrm{p}+\mathrm{f}>\mathrm{s}+\mathrm{c}_{1}+\mathrm{c}_{2}$. But if such circumstances do not exist, the Kline rule that $p+f<s+c_{1}+c_{2}$ would still be valid. Kline indicated $f=s$, and if this wcre so, even $p$ at a maximum would not suffice to change the inequality. The change to $f>g$ permits the injunction in these special circumstances.

All the situations thus far presented by concurrent proceedings involved two actions brought by the same party as plaintiff in both cases. Consideration must be given to other possible configurations. The state court defendant, if he were a resident of the state and therefore unable to remove the action on grounds of diversity, might bring an action 
Possibly a harassed defendant might request a state court injunction against all future litigation in federal courts. ${ }^{09}$ Here it is quite clear that the defendant's interest is less than in Donovan. The harm consists of a threat of future litigation only, and is obviously less than when litigation has actually begun. And, again, the federal remedies discussed above would become available when the threatened suit is instituted.

Finally, defendant might want protection against the possibility of multiple suits in the federal courts. For example, suppose a harassing plaintiff sues defendant in the Texas state court and in the federal district courts in Texas and Oklahoma. If the defendant were required to go into both federal courts and plead res judicata or request a stay, the harm incurred by him might be greater than the harm in Donovan

in the federal courts for declaratory relief in order to defeat state court plaintiff's choice of forum. In seeking a state-federal injunction in this situation, state court plaintiff would claim he was being both deprived of his choice of forum and harrassed by being forced to litigate his claim twice. The latter harm to him is of the same type as the harm to the Donovan defendants; the former appears to be of a different type. However, an examination of the Declaratory Judgment Act, 28 U.S.C. $\$ \S 2201-02$ (1958) and of FED. R. Crv. P. Rule 57, governing declaratory judgments, reveals that state court plaintiff's loss of his choice of forum through defendant's declaratory judgment action is not a harm which a state court can remedy by issuing an injunction. The Act commits the exercise of jurisdiction to the discretion of the federal judge. Rule 57 allows the judge to exercise his discretion even where a state remedy, such as defending the state action, exists for the party seeking declaratory relief. The Act and the Rule clearly allow for the plaintiff's choice of forum to be defeated in certain circumstances. Thus, the harm with which state courts can legitimately concern themselves in the declaratory judgment context are not greater than the harm to the parties in Donovan. The federal remedies available to prevent this harm are greater in the declaratory judgment context. Not only are the full range of harassing litigation remedies available-res judicata, stajs, ctc-but the state court plaintiff can plead that the federal judge should not in his discretion take the case. Federal courts have shown they will not entertain declaratory actions where their effect is to harass a party-Brillhart v. Excess Ins. Co., 316 U.S. 491 (1942); 6 Moone, FeoeruL PRACTICE If 57.08[5] (2d ed. 1953) - or where such action would interfere with prior state proceedings-Id. at I 57.08[6]. Since the potential harm in this context is less than in Donovan and the remedies available are more extensive, the parties interest in obtaining a state-federal injunction is less than in Donovan.

A slightly different context in which state court plaintiff might seek a state-federal injunction would be where state court defendant ignores a state's compulsory counterclaim rule and brings an independant action for his claim in federal court. In this situation state court plaintiff suffers some harassment in being forced to litigate the same transactionthe common test for a compulsory counterclaim-in more than one court. He also loses his choice of forum with respect to the counterclaim (of course, he still has his choice for his original cause of action). However, since both these elements of harm are less than that suffered by the party in the declaratory judgment situation, they are also less than that in Donovan. The remedies available to the party are the same as those available to the Donovan defendants. Therefore, the parties interest in this context is less than in Donovan.

69. The usual unqualified permanent injunction enjoins all future actions in any court. See e.g., Donovan v. City of Dallas, 377 U.S. 408, 410 (1964). 
where the defendant was forced to appear in only one federal court. However, in the supposed case defendant could obtain from either federal court an injunction against the other. ${ }^{70}$ Thus, the multiple suit situation would be reduced to a single federal action.

It seems clear from what has preceded that the interest of the parties suing for the injunction in the Donovan litigation was stronger than the interest of the suing parties in any imagined alternative. Unless it is possible to find a federal interest weaker than the federal interest in Donovan itself the comprehensive Donovan rule must be approved. Like the states, the federal government has an interest in ensuring access to its courts, and protecting its courts' judgments and jurisdiction. Donovan protected access and jurisdiction. It has already been shown that protecting a court's prior judgment involves a greater governmental interest. ${ }^{71}$

Perhaps it is possible to argue that the federal interest in protecting its diversity jurisdiction would be weaker than its interest in Donovan (federal question jurisdiction). Blanchard v. Commonwealth Oil Co. could be cited as indirect support for this proposition. ${ }^{22}$ That case rests, however, upon a distinction between federal question and diversity jurisdiction which has no support in either the Constitution or legislation. The Constitution provides equally for both modes of jurisdiction. ${ }^{73}$ And since Congress granted the courts jurisdiction over diversity cases nearly one hundred years before it granted original jurisdiction to decide federal questions, ${ }^{74}$ federal legislation certainly does not support the superiority of federal question jurisdiction.

70. See Martin v. Graybar Elec. Co., 266 F.2d 202 (7th Cir. 1959); Barbcr-Grecne Co. v. Blaw-Knox Co., 239 F.2d 774 (6th Cir. 1957). Sce also 2 Moore, Federal Pracrice If 3.06[2] at 735, n.11 (2d ed. 1964). The federal courts have enjoined one another on the mere showing of concurrent actions involving the same parties and issucs.

71. See notes $42-45$ supra and accompanying text. As to any distinctions between the interest in protecting access and jurisdiction, see Dombrowski v. Pfister, 380 U.S. 479, 481 \& $n .2$ (1965); 1A MoORE, Federal Practice \ 0.229[1] (2d ed. 1965).

72. 294 F.2d 834 (5th Cir. 1961). That court recognized the state-fcdcral injunction, which the state court had not enforced, when it decided the fedcral court should have dismissed the federal suit on the ground of comity instead of going to the mcrits and dismissing on the ground that a former state action was res judicata. The court explained:

Further, when the federal court is hearing a diversity case on a question of state law of the state issuing the injunction, as opposed to the situation where it is entertaining a suit on a federal cause of action, ... it is sitting as another state court and should be especially cognizant of state interests and policy.

Id. at 839.

73. U.S. ConsT. art. III, \& 2.

74. Diversity jurisdiction was first granted in the Judiciary Act of 1789, ch. 20, \& 11 , l Stat. 78. General federal question jurisdiction was not granted until 1875. Act of March 3, 1875, ch. 137, \& 1, 18 Stat. 470. 
The final two interests involved in Donovan are the interest in preventing interference between two courts and the interest in preventing conflicts between two sovereigns. The first is based on the desire for every court to determine the dispute before it without interference from external authority. ${ }^{75}$ The second is based on the natural desire to preserve harmony between different sovereigns. ${ }^{70}$ Both interests remain constant in all cases involving inter-system injunctions and are not relevant in determining whether there exists any stronger case than Donovan for issuing a state-federal injunction.

If the above analysis of possible interests is correct then the scope of the Donovan rule is not too broad. There are no cases which could present a stronger case for issuing a state-federal injunction. If the result in that litigation is accepted, the inclusive prohibition against state-federal injunctions must be accepted too. ${ }^{77}$ In fact, the rule announced in Donovan might be too narrorv, since there is no justification for the sweeping in rem exception. The Court's treatment of the exception is totally unacceptable. First, the exception is inconsistent with the plaintiff's "right" to a federal hearing ${ }^{78}$ upon which the Donovan Court relied so heavily. Second, the exception involves a concept "for which the standards are so elusive and confused generally and which, being primarily for state courts to define, may and do vary from state to state." 79 And third, the Court based the exception solely upon the authority of Princess Lida $v$. Thompson ${ }^{80}$ without making any attempt to elaborate its rationale.

The Princess Lida litigation, which involved the administration of a trust, began when the trustees filed an accounting with a state court.

\footnotetext{
75. The majority was careful to note this interest in non-interference could not be avoided by enjoining the parties rather than the court. Donovan v. City of Dallas, 377 U.S. 408, 413 (1964). But such distinctions are attempted. See id. at 420; Blanchard v. Commonwealth Oil Co., 294 F.2d 834, 839 (5th Cir. 1961). See also note 2 supra.

76. See Note, 90 U. PA. L. REv. 714 (1942). Cf. Story's doctrine of non-interference, STORY, EQUTTY JURISPRUDENCE \& 900 (Ist ed. 1836).

77. See note 14 supra.

78. See notes 30 and 32 supra and accompanying text.

79. Mullane v. Central Hanover Bank \& Trust Co., 339 U.S. 306, 312 (1950). The Court determined the requirements of the Due Process Clause on the basis of the interests of the parties and of the State of New York in the particular circumstances presented. Id. at $313-20$.

80. 305 U.S. 456 (1939). The same in rem exception was also recognized for federal-state injunctions. Toucey v. New York Life Ins. Co., 314 U.S. 118, 134-37 (1941). That exception has been criticized for its broadness. Taylor \&: Willis, The Power of Federal Courts to Enjoin Proceedings In State Courts, 42 YALE L.J. 1169, 1183 (1933). The Supreme Cour has never actually upheld a federal-state injunction to protect a federal court's control over property. See Hart \& We WersLer, The federal Courts ANd THE Federal Systess 1073 (1953).
} 
The following day the beneficiaries of the trust brought suit in a fecleral court against these trustees. To protect their choice of forum, the trustees moved for a dismissal in the federal court, claiming it lacked the possession of the res necessary for jurisdiction..$^{81}$ The trustee also obtained an injunction from the state court prohibiting the beneficiaries from further proceeding in federal court. But the federal court denied the trustees' motion to dismiss, holding that the state court jurisdiction was not exclusive. ${ }^{82}$ The Supreme Court resolved the conflict between the two courts by upholding the state-federal injunction, and by holding that prior possession of the res gave the state court exclusive jurisdiction. ${ }^{83}$ Donovan's reliance upon federal remedies to prevent state and federal court interference seems to undercut the validity of Princess Lida, since in that case there was an adequate federal remedy-a motion to dismiss. Thus, the reliance of Donovan upon Princess Lida is anomalous.

If the injunction in Princess Lida is inconsistent with Donovan, then clearly the distinction between cases in rem and in personam is not an adequate basis for determining the propriety of state-federal injunctions. In most cases the interests involved in an in rem case will not differ from those involved in an in personam case. ${ }^{84}$ There is one kind of in rem case, however, in which the parties' interest in avoiding duplicative suits is so distinguishable from the parties' interest in in personam cases that an injunction may be required. In this kind of case the plaintiffs in a state court seek protection from suits by other plaintiffs upon different causes of action against the same property. ${ }^{85}$ If the federal suit comes to judgment and disposes of the property before the state suit, the state court plaintiff can no longer obtain relief. ${ }^{86}$ The federal court affords little protection for the plaintiff since he is not a party to the federal suit. In this situation the plaintiff's

81. 305 U.S. at 459.

82. Id. at 460-61. Previously the federal district court had temporarily enjoined the federal court defendants from proceeding in the state court to enjoin the federal court plaintiffs from having the jurisdictional issue tried in the federal court.

83. Id. at $467-68$.

84. In Princess Lida the trustees wished to maintain their choice of forum and to avoid the harassment of duplicative suits. This is identical to the parties' interest set out in the discussion in note 68 supra.

85. An analogous example of the type of case being discussed is a bankruptcy action. Of course, the Bankruptcy Act provides for full federal control and the power to cnjoin all other actions. Bankruptcy Act $\$ \$ 2 a(15), 11 a, 30$ Stat. 546 (1898), 66 Stat. 422 (1952), 11 U.S.C. $\$ \S 11 a(15), 29 a(1958)$.

86. See 45 AM. JUR. Receivers $§ \S 158,162$ (1943). Injunctions lie to protect the property in receivership from actions that may interfere with the orderly handling of the assets. 
interest in obtaining a state court injunction would outweigh the interest of the requesting parties in Donovan, and therefore that case would not prevent the injunction.

Except for this kind of in rem suit, though, acceptance of the result in Donovan forces acceptance of the Court's broad in personam rule, and requires rejection of the court's blanket in rem exception. The facts in Donovan cannot be distinguished away. If that case is disapproved it must be met directly. Commentators (or future courts) who attack the rule, but who do not attack the result in that particular case and the assumption of a predominant federal interest upon which it is based, cannot succeed. 